\title{
Quality indicators and shelf life of red octopus (Octopus maya) in chilling storage
}

\author{
Mariel GULLIAN-KLANIAN ${ }^{1 *}$, María José SÁNCHEZ-SOLIIS ${ }^{1}$, Montserrat TERRATS-PRECIAT ${ }^{1}$, \\ Mariana DELGADILLO-DÍAZ ${ }^{1}$, Javier ARANDA ${ }^{1}$
}

\begin{abstract}
There are no precedents concerning the quality of Octopus maya during chilled storage. This study evaluated the shelf life of the red octopus in chilling storage $\left(4^{\circ} \mathrm{C}\right)$ and the correlation of the sensory quality index with microbiological counting and the biochemical indicators (hypoxanthine, histamine and volatile amines). A total of 112 whole raw octopuses (average weight of $896 \mathrm{~g}$ ) were randomly selected from seven batches and exposed to $4^{\circ} \mathrm{C}$ for $18,24,48,72,84,96$, and $100 \mathrm{~h}$. The histamine concentration (91.7\%), followed by the counts of psychrotrophic bacteria (5.5\%) and hypoxanthine (2.2\%), were the predictors from the redundancy analysis that better explained the changes taking place during the chilling hours. After $72 \mathrm{~h}$ of chilling, the microbial count was determined to be $\log 4.7 \mathrm{CFU} / \mathrm{g}$, and the octopus samples were classified as B quality (minor sensory quality defects) based on the sensory quality scale. Although the samples were not classified as unacceptable at $100 \mathrm{~h}$ of refrigeration by the sensory index, the level of histamine reached the defect action level $(5 \mathrm{mg} / 100 \mathrm{~g})$ as ruled by the International Food Safety Authorities. The shelf life of the red octopus in chilling storage was predicted to be $119 \mathrm{~h}$.
\end{abstract}

Keywords: Octopus maya; sensory quality; biochemical parameters; chilled storage

Practical Application: Biochemical quality standards for the octopus industry.

\section{Introduction}

Post-mortem deterioration of the octopus muscle is associated with several factors involving enzymatic and microbial activities, which contribute to limit its shelf life during storage (Hu et al., 2012). Temperature control is the most important physical factor for the preservation of seafood, and it is also important for the prediction of the remaining days of the shelf life of a product. It is known that if fresh seafood is properly handled and kept at low temperatures, the bacterial growth is reduced and other spoilage factors are controlled (Sharifian et al., 2014). However, since biochemical changes occur even when seafood is kept under cool conditions, long-term storage is not recommended (Hamada-Sato et al., 2005).

Octopus maya, a benthic octopus with holobenthic hatchlings, is endemic to the Yucatan Peninsula and a unique species among the 150 known species of octopus worldwide (Solís-Ramírez, 1997). This artisanal fishing resource is one of the most important commercially exploited species in Mexican fisheries with great demand in the European Union (EC) due to its size (between $60 \mathrm{~cm}$ and a meter long) and the texture of the meat. Since the year 2000, octopus catches have changed substantially—from approximately 6,000 t (in 2005 and 2008) to the maximum at around $24,527 \mathrm{t}$ produced during 2014 . The quality index method (QIM) established by the Mexican Official Norm (1993) (NMX-F-535) is the commonly used method for quality assessment of fresh octopus in the octopus industry. The NMX-F-535 criteria and freshness categories are in agreement with the European Commission grading scheme for cephalopods and classify octopus into three quality levels: A (good quality), B (satisfactory quality), and unacceptable quality (below level B) (Mexican Official Norm, 1993; European Commission, 1996). The NMX-F-535 level A combines the Extra and A categories from the EU scale, and the NMX-F-535 level $\mathrm{B}$ corresponds to the category B from the EU scheme.

The effect of chilling storage on protein denaturation has been the subject of study in fish for several years and continues to be studied (Jiang et al., 2013; Bermúdez-Aguirre \& Welti-Chanes 2016; Mikš-Krajnik et al., 2016). Nevertheless, it is noteworthy that there has been little research done on quality changes in octopus species in the worldwide; in particular for O. maya, the effect of chilling storage on the protein denaturation has not been previously reported. To date, some authors have developed a sensorial scheme specific for whole iced Octopus vulgaris based on the quality index method (Barbosa \& Vaz-Pires, 2004). Those authors reported that the shelf-life of $O$. vulgaris is much shorter than that of fish species, which was 8 days on ice measured by sensory attributes. There are major differences between O. maya and O. vulgaris, starting with their development cycle and depth distribution. O. maya is a benthic octopus with holobenthic hatchlings, missing the paralarval phase. O. maya comes from artisanal fisheries and the microbiological load that brings the organism in the catch is always greater than $O$. vulgaris. This endemic species is fished in coastal areas at 
2-5 fathom depth, unlike O. vulgaris, which is caught at depths between 10 and 20 fathoms (González de la Rosa et al., 1998). The fishing time of $O$. maya varies depending on winds, from 3 to $5 \mathrm{~h} /$ day; compared to O. vulgaris which is an industrialized fishing and it has an uninterrupted fishing time of 10-12 days before arrival to the coast. Due to the proximity to the coast and the rudimentary conservation of ice on boats, the major concerns of $O$. maya fishing are the absence of food safety and the lack of specific quality.

Concerning $O$. maya, little research has been done, preventing the establishment of quality indicators to predict the degree of deterioration of the product in relation to sensorial changes. The aims of this study were (1) to determine the shelf life of the red octopus after capture and chilling storage using the sensory quality index and (2) to correlate the sensorial scale with quantitative indicators of freshness, safety and spoilage (3) to determine the presence of foodborne pathogenic microorganisms. The results of the present study can be used advantageously in the octopus industry since concentrations of the biochemical indicators allow prediction of the degree of freshness of octopus before sensory changes are obvious.

\section{Materials and methods}

\subsection{Sample collection of fresh $O$. maya}

Specimens of $O$. maya were provided by six artisanal fleets operating in shallow waters (27 feet) off Sisal, State of Yucatán, México $\left(21^{\circ} 10^{\prime} 0^{\prime \prime} \mathrm{N}, 90^{\circ} 02^{\prime} 0^{\prime \prime} \mathrm{W}\right)$. The octupeses were caught during the fishing season between August $1^{\text {st }}$ and December $15^{\text {th }}$ 2014 using fishing equipment known as "jimba", which consists of a rod with several lines, and live crabs as bait. Fishermen catch the octopus for 5 to $7 \mathrm{~h}$ every day using vessels of 8-10 $\mathrm{m}$ (27 feet) long. The product is immediately eviscerated on board and refrigerated in coolers containing ice water at $2-6^{\circ} \mathrm{C}$. The time from the capture of the octopuses until arrival at the laboratory was 5 hours, however, zero time of the experiment starts from the moment that the product was stored in the ice containers of landing site.

\subsection{Sampling size and treatments}

The acceptability of octopi caught by each fisherman was determined based on the acceptance-sampling plan. The maximum fishing capacity of an artisanal fleet is $100 \mathrm{~kg} /$ day (approximately 90 to 100 specimens). The sample size for the sensory quality inspection was selected using Inspection Level II, with the acceptable quality limit of 6.5 (International Organization for Standardization, 1999). Thus, 20 specimens per fleet (sampling size) were randomly selected from each batch, individually packaged in polyethylene bags, and transported to the laboratory at $4{ }^{\circ} \mathrm{C}$ in a portable chest refrigerator (Shuttle ${ }^{\mathrm{TM}} 25 \mathrm{~N}$, Stirling Ultracold, Athens, OH, USA). Once in the laboratory, samples were randomly selected from seven batches $(n=16)$ and exposed to $4{ }^{\circ} \mathrm{C}$ (R-36 cooler, Tor-Rey Refrigeration, Inc., Norcross, GA, USA) for different times $(18,24,48,72,84,96$, and $100 \mathrm{~h}$ ). A total of 112 octopuses with an average weight of $896 \mathrm{~g}$ (range: 578-1,260 g) were analyzed successively for sensory quality, biochemical, and microbiological data. Temperature of exposition $\left(4^{\circ} \mathrm{C}\right)$ was selected based on the mean temperature of the ice containers of the landing site.

\subsection{Sensory quality of refrigerated $O$. maya}

Three trained assessors from a processing plant evaluated the sensory quality of the refrigerated octopi using the QIM proposed in the Mexican Official Norm (1993) (NMX-F-535-1993). Each assessor scored skin color, muscle odor, skin texture, and the external odor, where 0 points represented the best quality and any higher score indicated poorer quality. The final quality index (QI) of the product was based on the system of deductions with the base of 100 (QI accumulated), which represents a modification of the Torry scale for freshness (Shewan et al., 1953). A score of each characteristic (demerit point) was added to give an overall sensory score and then subtracted from 100 points to get the final QI. The limit of acceptability for quality was 85 points; fresh octopi with 90 to 100 points were classified as category A (highest quality of freshness), and octopi between 85 and 90 points were classified as category B (minor sensory quality defects).

\subsection{Microbial counts}

Microbial counts were determined immediately after the sample arrival to the laboratory. Ten grams of the octopus was transferred aseptically to a stomacher bag with $90 \mathrm{~mL}$ of pre-chilled peptone-physiological saline solution (PPSS: $0.1 \%$ neutral peptone and $0.85 \% \mathrm{NaCl}$ ) and homogenized for $60 \mathrm{~s}$. Further decimal dilutions were prepared in PPSS, and $0.1 \mathrm{~mL}$ of each dilution was plated in duplicate on a number of growth media (Moini et al., 2012). The total viable bacteria counts were determined using Plate Count Agar (Difco Laboratories, Detroit, MI, USA). Plates were incubated at $25^{\circ} \mathrm{C}$ for five days for total viable psychrotrophic bacteria enumeration (Thomas, 2008). For isolation of different microbial groups, each dilution (as described above) was spread onto violet red bile glucose (VRBG) agar, thiosulfate citrate bile salt (TCBS) agar, mannitol salt agar (MSA), and cetrimide agar (CA). The samples on MSA were incubated at $30^{\circ} \mathrm{C}$ for 2-3 days for Staphylococcus aureus counts (yellow colonies). The VRBG and TCBS agar plates were incubated at $37^{\circ} \mathrm{C}$ for $24 \mathrm{~h}$ for bacteria of the family Enterobacteriaceae and the genus Vibrio, while the CA plates were incubated at $26^{\circ} \mathrm{C}$ for $72 \mathrm{~h}$ for Pseudomonas counts.

\subsection{Biochemical parameters}

Histamine concentration was determined according to AOAC method 070703 (Association of Official Analytical Chemists, 2007) using the Neogen Veratox enzyme-linked immunosorbent assay. An octopus tissue sample was treated and prepared for analysis according to AOAC method 937.07 (Association of Official Analytical Chemists, 2007). The results were compared with a standard curve measuring absorbance against histamine concentrations (0-6 mg/100 g).

Hipoxanthine (Hpx) concentration was determined according to the Analytical Methods Committee guide (Analytical Methods Committee, 1978). A 5-g sample of the octopus muscle was accurately weighed, macerated with $50 \mathrm{~mL}$ of $0.6 \mathrm{M}$ perchloric acid, and filtered through Whatman No. 4 filter paper. A volume of $5 \mathrm{~mL}$ of the filtrate was mixed with $5 \mathrm{~mL}$ of a potassium hydroxide-phosphate buffer solution. Precipitated perchlorate was removed from the neutralized extract by centrifugation 
(Eppendorf 5804R, Hamburg, Germany). Then, $1 \mathrm{~mL}$ of the neutralized extract was transferred into a test tube containing $1.5 \mathrm{~mL}$ of water, $2.0 \mathrm{~mL}$ of $0.25 \mathrm{M}$ phosphate buffer ( $\mathrm{pH} 7.6$ ), and $0.5 \mathrm{~mL}$ of a diluted enzyme solution. After incubation at $37^{\circ} \mathrm{C}$ for $30 \mathrm{~min}$, the absorbance was measured at $290 \mathrm{~nm}$ in a UV-VIS spectrophotometer (Evolution ${ }^{\mathrm{TM}}$ 200, Thermo Fisher Scientific, Inc., Waltham, MA, USA). A series of standards in the range of $0-20 \mu \mathrm{g} / \mathrm{mL}$ of HPX (Sigma-Aldrich, H9377) were run at the same time as the samples. The HPX concentration $(\mu \mathrm{mol} / \mathrm{g})$ was calculated as the HPX concentration in the extract $(\mu \mathrm{g} / \mathrm{mL}) \times 0.1587$.

TMA nitrogen (TMA-N) was determined following the method described by Woyewoda et al. (1986). A 100-g sample of octopus tissue was homogenized in $100 \mathrm{~mL}$ of a $7.5 \%$ trichloroacetic acid solution and centrifuged in a refrigerated centrifuge (Eppendorf $5804 \mathrm{R}$ ) at $2,000 \times \mathrm{g}$ for $15 \mathrm{~min}$ at $4{ }^{\circ} \mathrm{C}$. Volumes of $1 \mathrm{~mL}$ of $10 \%$ formaldehyde, $10 \mathrm{~mL}$ of toluene, and $3 \mathrm{~mL}$ of $25 \% \mathrm{KOH}$ were added successively to $2 \mathrm{~mL}$ of the extract, as previously described. An aliquot of $7 \mathrm{~mL}$ of the resulting solution was removed from the upper toluene layer and transferred to a tube containing approximately 0.3 to $0.4 \mathrm{~g}$ of anhydrous $\mathrm{Na}_{2} \mathrm{SO}_{4}$. Then, $5 \mathrm{~mL}$ of this solution was added to $5 \mathrm{~mL}$ of a picric acid working solution to develop the color. The absorbance was measured at $410 \mathrm{~nm}$ in the Multiskan microplate spectrophotometer. The results were compared with a standard curve using TMA-N (Sigma-Aldrich, $317594)$ as a standard (0-5 mg).

Total volatile base nitrogen (TVB-N) was determined following the method described by Woyewoda et al. (1986). Briefly, $10 \mathrm{~g}$ of octopus tissue was blended in $50 \mathrm{~mL}$ of distilled water at a high speed for $2 \mathrm{~min}$ and centrifuged at 5,000 rpm for $4 \mathrm{~min}$. Several drops of antifoam concentrate and $0.3 \mathrm{~g}$ of $\mathrm{MgO}$ were added to each sample prior to connecting the flask to a fractionating column. Distillation was carried out using vertical distillation units (Buchi-K-350, Butterworth Labs, UK). Steam distillation was continued until $150 \mathrm{~mL}$ of liquid was collected in a $250-\mathrm{mL}$ Erlenmeyer flask containing $20 \mathrm{~mL}$ of $3 \%$ boric acid and 3 drops of Kjeldahl indicator solution $(0.1 \%$ alcoholic solution of methyl red and $0.1 \%$ alcoholic solution of methylene blue). The green alkaline distillate was back-titrated with $0.1 \mathrm{~N}$ sulfuric acid to its original purple color. TVB-N was expressed as $\mathrm{mg} \mathrm{N} / 100 \mathrm{~g}$ of sample.

Tissue $\mathrm{pH}$ was measured by a potentiometric method based on direct determination of $\mathrm{pH}$ in a suspension of the octopus muscle in distilled water (1:2) (Scott et al., 1988). The $\mathrm{pH}$ was measured at $25^{\circ} \mathrm{C}$ by a pH meter (Oakton benchtop pH 510 meter, Vernon Hills, IL, USA).

\subsection{Statistical analyses}

The biochemical parameter data are represented as the mean and standard error. Before the statistical analysis, the data distribution was verified by the Kolmogorov-Smirnov normality test, and then the data were subjected to a one-way analysis of variance. Redundancy analysis (RDA) was used to analyze the dependent effect of chilling hours and the quality index score (explanatory variables) on the set of biochemical and microbiological parameters (response variables). Canonical variate analysis (CVA) running with Hill's scaling and focusing on intervariable distances was used to provide an objective assessment of the similarity between the groups subjected to different chilling hours with respect to their biochemical and microbiological parameters (response variables). The Monte Carlo test with 500 permutations was used to select significant variables to be included in the RDA and CVA. The predictors were accepted with a type I error probability estimate less than a $/ \mathrm{Nc}$ (Bonferroni correction), where $\mathrm{Nc}$ is the number of independent variables used in the analysis (Legendre \& Legendre, 1998). The principal response curve (PRC) method based on a partial RDA was used to plot the significant association between the best significant parameter (response variable) and the QI values. Analyses were performed using the SPSS 18.0 and Canoco 4.5 software for Windows. Diagrams were plotted with the Canodraw 4.0 graphics software.

\section{Results and discussion}

\subsection{Sensory quality data}

The results of the present research showed the expected influence of the chilling time on O. maya quality. During the storage period, the octopus showed gradual changes in the texture, skin color, and muscle odor (Table 1). Fresh octopus was assessed as category "A" before $72 \mathrm{~h}$ of chilling $\left(4^{\circ} \mathrm{C}\right)$. After $72 \mathrm{~h}$, the octopus was scored between 85 and 90 points and classified as "B" quality. No samples were classified as unacceptable, even after $100 \mathrm{~h}$ of refrigeration, suggesting a gradual but slow deterioration.

The results of linear regression between the chilling storage period and accumulated QI enabled the prediction of the point of product rejection at $119 \mathrm{~h}$ (five days) (Figure 1). At this point, the quality of octopus is reduced below 85 points, making the product unacceptable for human consumption. The shelf life of five days found in the present study for red octopus is lower than of the 6-8 days reported by other authors for common octopus, O. vulgaris (Hurtado et al. 1999; Barbosa \& Vaz-Pires, 2004). The difference of 1-3 days in the shelf life between the octopus species is probably due to the mean temperature of storage, the criteria of the freshness scale, or the intrinsic properties of the species (Ashie et al. 1996; Dalgaard, 2000). There are major differences between $O$. maya and O. vulgaris, in particular

Table 1. Sensory quality parameters of Octopus maya using the quality index method (QIM). Data represents mean; $n=16$ octopus.

\begin{tabular}{ccccccc}
\hline $\begin{array}{c}\text { Storage } \\
\text { period } \\
(\mathrm{h})\end{array}$ & $\begin{array}{c}\text { Muscle } \\
\text { odor }\end{array}$ & $\begin{array}{c}\text { Skin } \\
\text { texture }\end{array}$ & $\begin{array}{c}\text { Skin } \\
\text { color }\end{array}$ & $\begin{array}{c}\text { QI } \\
\text { demerit } \\
\text { points }\end{array}$ & $\begin{array}{c}\text { QI } \\
\text { accumulated }\end{array}$ & Quality \\
\hline 18 & 0.91 & 0.91 & 1.27 & 3.09 & 96.91 & $\mathrm{~A}$ \\
24 & 1.17 & 1.33 & 2.00 & 4.50 & 95.50 & $\mathrm{~A}$ \\
48 & 1.09 & 2.00 & 3.09 & 6.18 & 93.82 & $\mathrm{~A}$ \\
72 & 4.36 & 2.91 & 2.73 & 10.00 & 90.00 & $\mathrm{~A}$ \\
84 & 3.00 & 3.17 & 4.33 & 10.50 & 89.50 & $\mathrm{~B}$ \\
96 & 5.83 & 2.33 & 4.00 & 12.17 & 87.83 & $\mathrm{~B}$ \\
100 & 3.17 & 3.67 & 6.33 & 13.17 & 86.83 & $\mathrm{~B}$ \\
\hline
\end{tabular}

Data represents mean; $n=16$ octopus. 


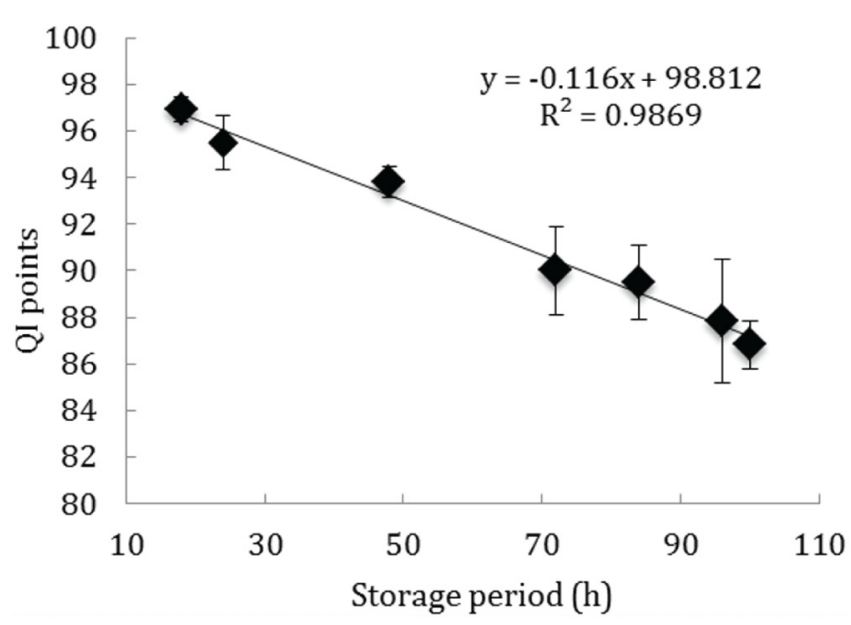

Figure 1. Correlation between accumulated quality index (QI) of Octopus maya with chilling hours. Different letters indicate significant differences at $p=0.05$ of confidence level $(F=3.78 ; P=0.001)$. Point represents mean \pm SEM $(n=16)$.

their depth distribution. O. maya is fished in coastal areas at 2-5 fathom depth, unlike O. vulgaris, which is caught at depths between 10 and 20 fathoms (González de la Rosa et al., 1998). This explains why the initial bacterial concentration in O. maya was higher $\left[>10^{6}\right.$ colony-forming units $\left.(\mathrm{CFU}) / \mathrm{g}\right]$ than that reported by Hurtado et al. (2001) for O. vulgaris $\left(10^{4} \mathrm{CFU} / \mathrm{g}\right)$. Since bacterial concentrations are higher in shallow waters than in deeper waters, the octopus comes ashore with a high intrinsic bacterial concentration (Sieburth, 1971). In addition, $O$. maya fishing takes place in surrounding areas near the port base and is performed by small-scale boats ( 27 feet long), which carry little ice on board, so that in the first 4-5 h of capture the internal temperature of the product drops slowly, which promotes microbial growth. This is not the case with $O$. vulgaris, which is captured by a larger-scale ships (40-70 feet long) equipped to travel further into deeper waters.

The grading of the sensory freshness scale proposed by the Mexican Official Norm (1993) (NMX-F-535-1993) and applied at processing plants is based on three parameters of the octopus skin. This provides a rapid and precise score for the evaluation of the sensorial quality of octopus, with minimal or no dissimilarity between assessors. It is possible, however, that this scale is less accurate than the scale of 10 criteria, proposed by Barbosa \& Vaz-Pires (2004) for O. vulgaris. A further study should focus on the evaluation of the freshness of red octopus using the sensory scale proposed by Barbosa \& Vaz-Pires (2004) for O. vulgaris. Thus, it will be possible to compare the accuracy between both sensory scales and reject or accept our main hypothesis that the difference is due to intrinsic characteristics of the muscle. O. maya is commercially appreciated not only for its size but also for the texture of its edible part, an organoleptic characteristic, which has not previously been studied.

\subsection{Microbial variation}

The complete data on microbial variation versus the chilling time are shown in Figure 2. The initial concentration of psychrotrophic bacteria was high in the first $18 \mathrm{~h}$ of storage

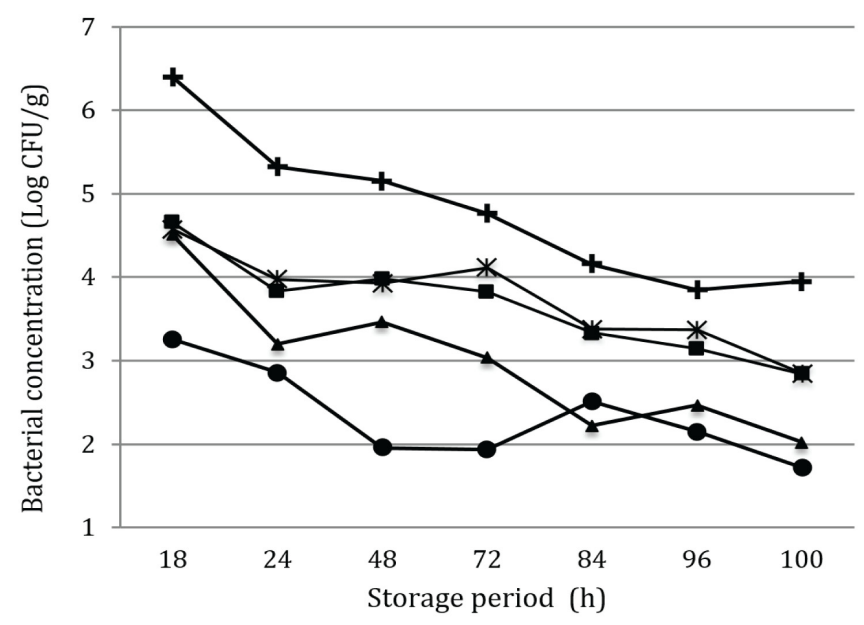

Figure 2. Variation of bacterial concentration of Octopus maya at different chilling hours. Point represents mean $(n=16)$; + Total psychrotrophic bacteria; X Staphylococcus aureus; - Enterobacteriaceae; $\bullet$ Pseudomonas sp.; $\Delta$ Vibrios sp.

(log $6.4 \mathrm{CFU} / \mathrm{g})$, and the concentration significantly decreased $(F=19.4, p<0.0001)$ to $\log 5.3 \mathrm{CFU} / \mathrm{g}$ after 24 of chilling. The decline was more pronounced in the number of enterobacteria, which decreased significantly from log 4.6 to $4.0 \mathrm{CFU} / \mathrm{g}$ after $18 \mathrm{~h}$, remaining at $\log 3.5 \pm 0.6 \mathrm{CFU} / \mathrm{g}$ up to $100 \mathrm{~h}$ of chilling $(F=9.29, p<0.0001)$. Psychrotrophic are capable of growth at temperatures below $7{ }^{\circ} \mathrm{C}$, although their optimum growth temperature may lie between 20 and $30^{\circ} \mathrm{C}$ (McPhee \& Griffiths, 2011). Nevertheless, the minimum growth temperature of the Enterobacteriaceae is heterogeneous. The values vary from $1.3^{\circ} \mathrm{C}$ for Enterobacter agglomerans, $1.6^{\circ} \mathrm{C}$ for Escherichia vulneris, $2.0^{\circ} \mathrm{C}$ for Serratia fonticola, and up to $8.7^{\circ} \mathrm{C}$ for Escherichia coli (Ridell \& Korkeala, 1997). In general, the optimal growth temperature of the Enterobacteriaceae is between 25 and $37^{\circ} \mathrm{C}$.

Many bacteria are unable to grow at low temperatures but can survive storage in the cold. Generally, numbers of viable bacterial cells decrease with time during refrigerated storage. Other bacteria, including Clostridium and Bacillus cereus, and some spoilage organisms, are psychrotrophic and can grow at refrigeration temperatures; however, growth during chilled storage is usually slow (Gram \& Dalgaard, 2002). The decreasing concentration of psychrotrophic bacteria during the first 24 hours of cooling suggests the effect of environmental factors influencing microbial adaptation, in particular thermal and saline shock. In particular thermal and saline shock is more pronounced in microorganisms of fish and shellfish from tropical and saline environment than in organisms from cold waters. Total bacteria counts on the fish skin have been reported by some authors as $10^{3}$ to $10^{5}$ and $10^{2}$ to $10^{7} / \mathrm{cm}^{2}$, but, as already noted, this variation may be accounted by effects of environmental factors, primarily temperature. Kraft (1992) reported that fish from cold waters where the temperature of the sea is $10^{\circ} \mathrm{C}$ of less may have counts at the lower end of the range, particularly with storage of the fish in melting ice. The bacterial flora is primarily psychrotrophic or psychrophilic Gram-negative rods. Fish from tropical or subtropical areas harbor more mesophilic bacteria which may 
be predominantly Gram positive. Thus, in accordance with Kraft (1992) changes in the microflora during chilling and storage are more pronounced in fish from tropical water than in fish from colder water. Liston (1980) reviewed the many sources of contamination of fish and shellfish from the time they are caught through the period on board ship and stored in ice. The Gram -positive mesophilic flora that is initially acquired by the fish and shellfish from environmental source is generally transient and does not compete well with psychrotrophs during later processing and refrigerated storage. As noted by Liston (1980) the microbial flora of marine organisms should be considered as euryhaline rather than as halophilic, even though their growth is enhanced by 2 to $3 \%$ salt. Since ice is commonly used for chilling fish, the salt level in the environment of the bacteria continues to be diluted and more nearly approaches that of fresh water as storage in ice progresses. Microorganisms that can adapt to changes in salt level are those that persist and grow.

The concentration of S. aureus significantly decreased by log $0.9 \mathrm{CFU} / \mathrm{g}$, after $18 \mathrm{~h}$ of chilling and remained relatively steady after that time $(F=6.07, p<0.0001)$. The presence of $S$. aureus in the octopus $(\log 3.7 \pm 0.6 \mathrm{CFU} / \mathrm{g})$ was not expected since this bacterial species does not originate in seawater. S. aureus, a major foodborne pathogen, is part of the microflora of the skin and nasal mucosa in humans. The presence of $S$. aureus in seafood is clearly a result of cross-contamination during harvest and post-harvest handling. Once $S$. aureus colonizes octopus, the bacterium grows, since it tolerates $25 \%$ sodium chloride and temperatures in the range between 4 and $46^{\circ} \mathrm{C}$. However, our results demonstrated that the microorganism did not reach an infective dose under chilling conditions. A concentration of $10^{6} \mathrm{CFU} / \mathrm{g}$ in food is required to produce toxins at hazardous concentrations, which is possible when the bacterium grows under the optimum conditions of $3.5 \% \mathrm{NaCl}$ and $37^{\circ} \mathrm{C}$ (International Commission of Microbiological Specifications for Foods, 1996). While $S$. aureus may grow at $7{ }^{\circ} \mathrm{C}$, the toxin is not produced below $10^{\circ} \mathrm{C}$, and very limited amounts are produced between 10 and $20^{\circ} \mathrm{C}$ (Adams \& Moss, 2000).

The significant reduction of Vibrio spp. from log 4.5 to $3.2 \mathrm{CFU} / \mathrm{g}$, after $18 \mathrm{~h}$ of chilling was not unexpected $(F=9.00, p<0.0001$; Figure 2). The growth of Vibrio spp. optimally occurs around $37^{\circ} \mathrm{C}$, with the minimum and maximum growth temperatures between -5 and $43{ }^{\circ} \mathrm{C}$, respectively. Other authors reported that the concentration of Vibrio spp. decreased from $\log 2.23 \mathrm{CFU} / \mathrm{g}$ to $\log 1.97 \mathrm{CFU} / \mathrm{g}$ after 10 days of storage at $5-8^{\circ} \mathrm{C}$, which confirms that the concentration decreases with increasing chilling time (Burnham et al., 2009). Likewise, in the present research the concentration of Pseudomonas spp. was low for all treatments $(\log 2.3 \pm 0.6 \mathrm{CFU} / \mathrm{g})$ without showing a significant change over time $(F=2.17, p<0.055)$. This result is inconsistent with the data obtained by Jiang et al. (2013), who reported that Pseudomonas was the predominant bacterial organism (up to $\log 6 \mathrm{CFU} / \mathrm{g}$ ) in fish stored at $4{ }^{\circ} \mathrm{C}$. The genus Pseudomonas combines species of psychrotrophic and mesophilic bacteria with the ability to grow in different temperature ranges (Ercolini et al., 2009). Generally, seafood contains psychrophile and non-proteolytic Pseudomonas spp. with an optimal growth temperature between 10 and $15^{\circ} \mathrm{C}$. These differences may explain the conflicting results reported by different authors.

\subsection{Influence of chilling time on biochemical parameters}

The freshness parameters of the octopus muscle were significantly influenced by the chilling time (Figure 3 ). The results from the multivariate RDA demonstrated that (1) the deterioration of the octopus muscle was dependent $(90.5 \%)$ on the chilling hours $(F=706.8, p=0.002)$ and (2) the variability of the octopus QI was dependent $(28.1 \%)$ on the biochemical parameter values $(F=4.83, p=0.003)$. The histamine level was a predictor that better explained $(91.7 \%)$ the variation of the explanatory variables $(F=394.1, p=0.002)$, followed by the psychrotrophic bacteria count $(5.5 \%)(F=28.3, p=0.002)$ and the HPX concentration $(2.2 \%)(F=15.5, p=0.004)$. TMA-N $(F=2.96, p=0.07)$ and TVB-N $(F=2.56, p=0.12)$ were not significant predictors.

The influence of biochemical and microbiological predictors on the groups subjected to different chilling hours was revealed by the CVA (Figure 4). The CVA clearly showed the data discrimination between three particular groups, where 18 and $72 \mathrm{~h}$ were the breakdown points $(F=6.52, p=0.0010)$. At $18 \mathrm{~h}$, the discrimination was significantly explained $(26.5 \%)$ by the lower psychrotrophic bacterial concentration $(F=9.39$, $p=0.001)$. At $72 \mathrm{~h}$, however, the variability was explained $(44.6 \%)$ by the increased histamine concentration $(F=14.4$, $p=0.001)$. The variation of the $\mathrm{pH}$ values $(6.10 \pm 0.04)$ was not significant. The PRC showing the relation between the histamine concentration and QI is presented in Figure 5.

Histamine is usually associated with seafood-related public health problems, in particular it is linked to scombroid fish poisoning. There is no precedent of acute histamine intoxication due to direct consumption of octopus, but other authors have previously reported an increase in the histamine concentration with extended chilling hours. Hu et al. (2012) reported that the contents of biogenic amines, in particular putrescine, cadaverine, and tyramine, increased above $100 \mathrm{mg} / \mathrm{kg}$ after five days of chilling storage in octopus purchased at a supermarket and stored at $4^{\circ} \mathrm{C}$; however, this was not observed for histamine whose range was 1.3 to $9 \mathrm{mg} / \mathrm{kg}$. The authors mentioned that the increase in biogenic amines was highly related to the growth of mesophilic and psychrophilic bacteria, except histamine for which no correlation was found. The formation of biogenic amines in aquatic products depends on several factors, such as the free amino acid contents, the presence of bacterial biogenic amine decarboxylases, and favorable environmental conditions (Ercolini et al., 2009). In this sense, the data reported by Hu et al. (2012) are difficult to compare with ours, since it is unknown how the samples were treated before the experiment. Based on the discussion provided by the authors, we believe that the low histamine concentration in the octopus samples was due to low levels of the microbial enzyme for decarboxylation of histidine. In other fishery products, such as mackerel (Scombridae) stored at $4{ }^{\circ} \mathrm{C}$ for eight days, the concentration of histamine increased above $50 \mathrm{mg} / \mathrm{kg}$ when the spoilage bacteria counts reached $10^{6} \mathrm{CFU} / \mathrm{g}$ (Jiang et al., 2013). In the present study, the maximum concentration of histamine $(42.5 \mathrm{mg} / \mathrm{kg})$ was reached at $100 \mathrm{~h}$ of chilling with a psychrotrophic bacteria concentration of $10^{4} \mathrm{CFU} / \mathrm{g}$. The initial concentration of psychrotrophic bacteria was high in the first $18 \mathrm{~h}$ of storage $(\log 6.4 \mathrm{CFU} / \mathrm{g})$, and the concentration 

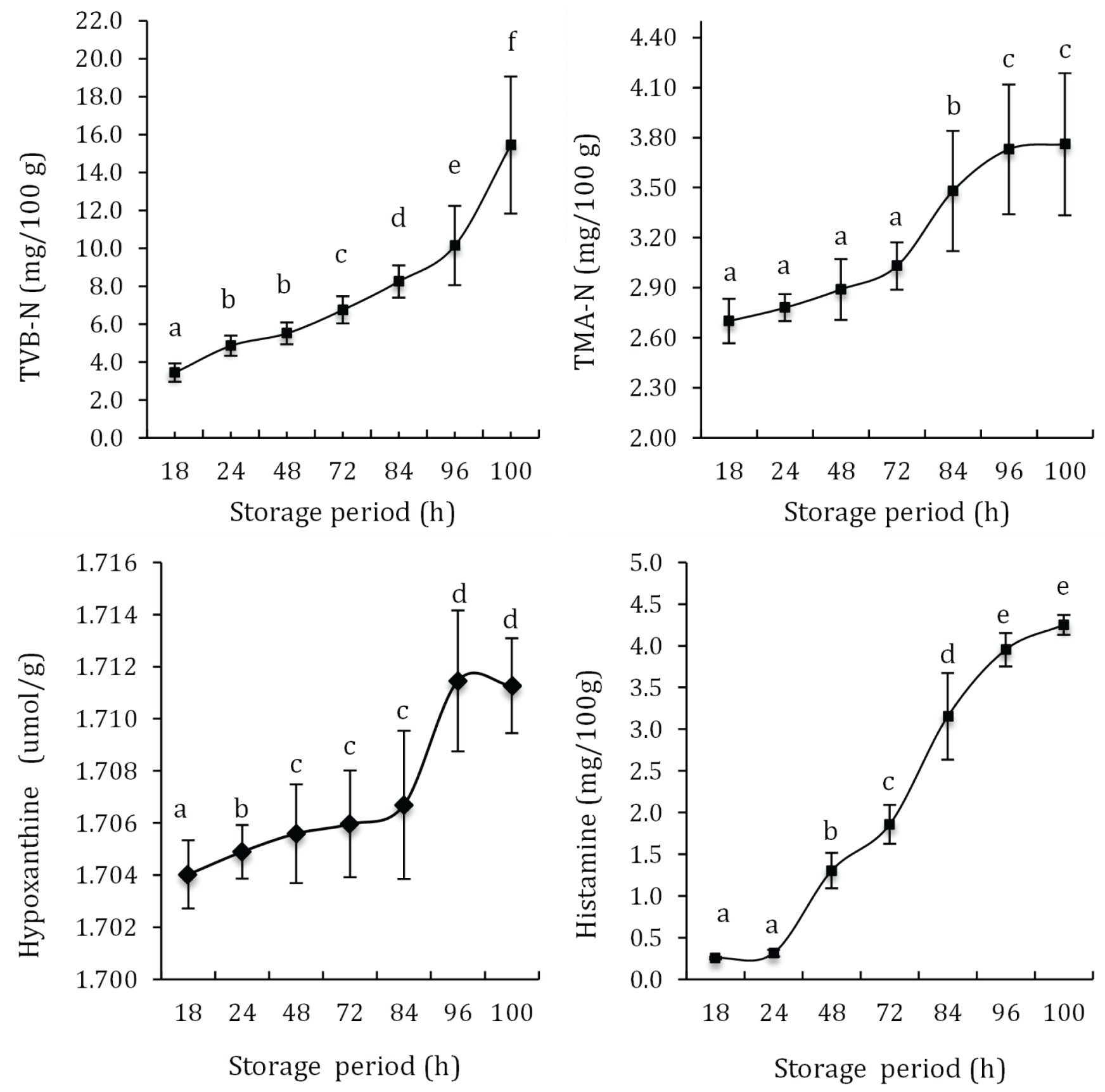

Figure 3. Variation of biochemical freshness parameters of Octopus maya at different chilling hours. Different letters indicate significant differences at $p=0.05$ confidence level. Point represents mean $\pm \operatorname{SEM}(n=16)$.

significantly decreased $(F=19.4, p<0.0001)$ to $\log 5.3 \mathrm{CFU} / \mathrm{g}$ after 24 of chilling, however, the level of histamine increased significantly after $48 \mathrm{~h}$. Generally histamine-producing bacteria are mesophilic and their concentration decreases with storage in chilling. The accumulation of histamine and TMA observed in the present study after 48 and $84 \mathrm{~h}$ of chilling, suggests the presence of psychrophilic histamine-producing bacterium. Torido et al. (2012) reported that strains of psychrophilic histamine-producing bacteria are known to produce large amounts of histamine, and they also cause the accumulation of large quantities of histamine in fish meat. Those authors detected an extremely high level of histamine accumulation $(1000 \mathrm{mg} / \mathrm{kg})$ within a week of storage at $4^{\circ} \mathrm{C}$ in the presence of Photobacterium phosphoreum. Takahashi et al. (2015) also reported high histamine accumulation $(>500 \mathrm{ppm})$ in cultures of Photobacterium iliopiscarium grown at $5^{\circ} \mathrm{C}$ after 3 days. Bacteria of the genus Photobacterium have been previously reported by Fichi et al. (2015) in O. vulgaris suggesting that those strains 


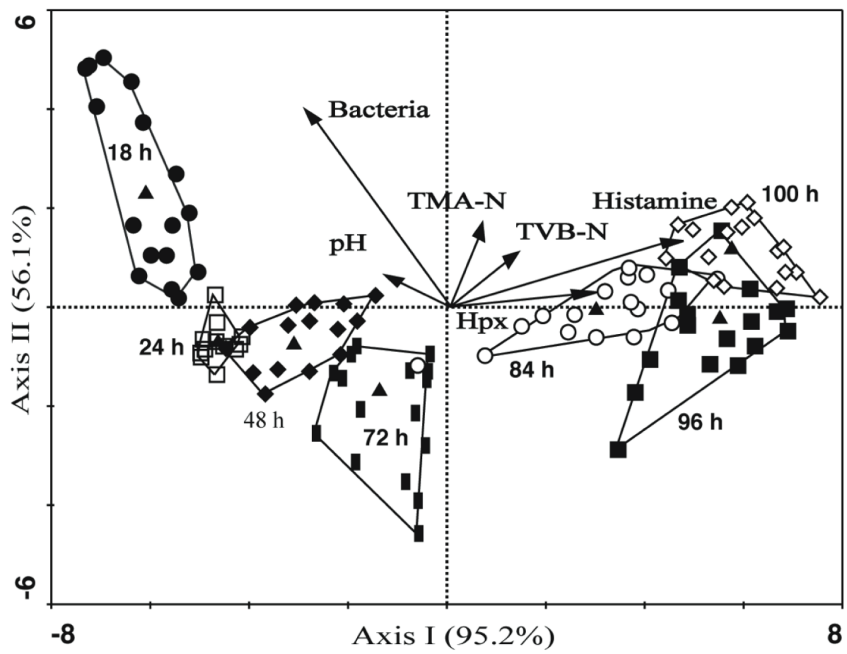

Figure 4. Canonical variant analysis (CVA) using biochemical and microbiological parameters as response variables. The samples from different chilling hours were aggregated by different polygons.

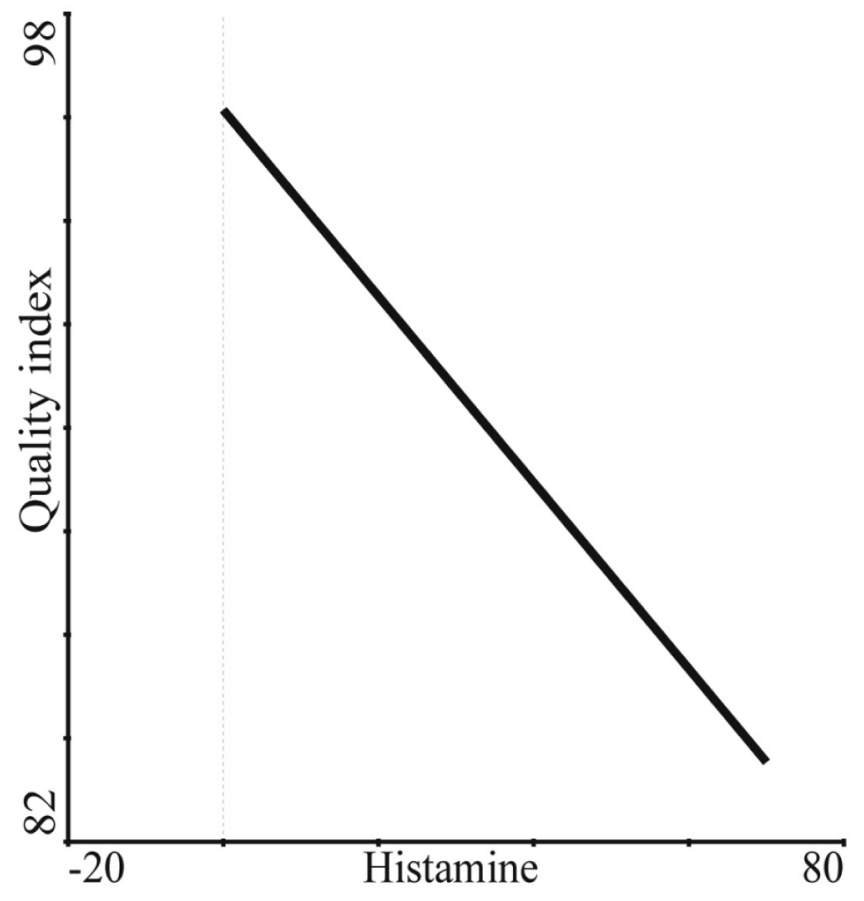

Figure 5. Principal response curve (PRC) analysis showing the significant association between histamine concentration from the raw Octopus maya and the quality index values.

could also be present in O. maya and even increase their activity in the absence of other competitive microflora.

The results of the present study demonstrated that the QI variability was dependent $(28.1 \%)$ on the biochemical parameter values. The subjectivity of the quality scale in assessing octopus spoilage agrees with previous reports. When sensory changes are obvious to consumers, some chemical parameters, such as histamine, may be at high levels. Despite all these uncertainties, Ten Brink et al. (1990) reported that higher levels of histamine (50-100 $\mathrm{mg} / 100 \mathrm{~g})$ are considered potentially hazardous to human health. Shalaby (1996), meanwhile, suggested the following guideline levels for the histamine content in seafood: $<5 \mathrm{mg} / 100 \mathrm{~g}$ (safe for consumption), $5-20 \mathrm{mg} / 100 \mathrm{~g}$ (possibly toxic), $20-100 \mathrm{mg} / 100 \mathrm{~g}$ (probably toxic), and $>100 \mathrm{mg} / 100 \mathrm{~g}$ (toxic and unsafe for human consumption). In Mexico and Europe, the maximum level permitted for histamine in refrigerated fishery products is $10 \mathrm{mg} / 100 \mathrm{~g}$ (European Commission, 2003; Mexican Official Norm, 2009). The US Food and Drug Administration guidelines have established $50 \mathrm{mg} / 100 \mathrm{~g}$ as the toxicity level and $5 \mathrm{mg} / 100 \mathrm{~g}$ as the defect action level for fish species implicated in histamine poisoning outbreaks, because histamine is not uniformly distributed in a decomposed fish (US Food and Drug Administration, 2001).

Our results suggested that both TVB-N and TMA-N are not significant indicators of early spoilage, but we agree that these parameters are critical for consumer decisions. TVB-N and TMA-N have been used in conjunction with sensory assessments as indicators of freshness. TVB-N has been highly correlated with the fish odor under chilling storage (Antoine et al., 2002). Botta (1995) mentioned that while TMA-N, TVB-N, and $\mathrm{NH}_{3}$ are used to measure fish deterioration, they are not useful for identifying sensorial changes in incipient stages of fish quality deterioration. TMA-N, meanwhile, has been proposed as an indicator of quality for some fish, but has not been proven to be a good indicator for others (Huss, 1995). In the present research, the TVB-N value significantly increased (from 6.75 to $8.25 \mathrm{mg} / 100 \mathrm{~g}$ ) after $72 \mathrm{~h}$ of chilling, when the octopus quality changed from category A to B. At the same time, TMA-N increased from 3.03 to $3.48 \mathrm{mg} / 100 \mathrm{~g}$. There are no TVB-N and TMA-N reference values reported for octopus during chilling storage; however, $8.25 \mathrm{mg}$ of TVB-N/100 g seems to be at a significantly lower level compared with the data reported for fish in chilling storage. The level of TVB-N was found to increase to up to $30 \mathrm{mg} / 100 \mathrm{~g}$ in the muscle of mahi-mahi fish (Coryphaena hippurus) after $72 \mathrm{~h}$ of refrigeration (Antoine et al., 2002). In contrast to TVB-N, the concentration of TMA-N found in O. maya after 72 chilling hours was higher than that in fish. The TMA-N content in refrigerated lean demersal fish reached $1.5 \mathrm{mg} / 100 \mathrm{~g}$ after five days, when the spoilage bacteria level was $\log 3 \mathrm{CFU} / \mathrm{g}$ (Antoine et al., 2002). At $72 \mathrm{~h}$ of chilling storage, the concentration of psychrotrophic bacteria in O. maya was $\log 5 \mathrm{CFU} / \mathrm{g}$, which is a likely reason for the high TMA level.

\section{Conclusions}

In summary, cumulative chilling hours greatly influenced the growth of microorganisms and the histamine production in octopus during the storage period. After $72 \mathrm{~h}$ of chilling storage, the octopus lost quality and was downgraded from category A to B. At this time, the concentration of histamine was low $(1.75 \mathrm{mg} / 100 \mathrm{~g})$; however, it significantly increased by $96 \mathrm{~h}$, reaching $5 \mathrm{mg} / 100 \mathrm{~g}$ (FDA's defect action level), while the decomposition parameters normally used for fish (TVB-N and TMA-N) were still below the decomposition levels in octopus tissues (15 mg/100 g for TVB-N and $3.76 \mathrm{mg} / 100 \mathrm{~g}$ for TMA-N). Based on the results, O. maya, with an international trade 
destination, would not meet the accepted quality standards after $96 \mathrm{~h}$ of refrigeration. However, it should be emphasized that the product had a lower quality (B quality) after $76 \mathrm{~h}$ of chilling according to sensory quality analysis.

\section{Acknowledgements}

The authors are grateful to Sr. R. Echeverria G. Canton from INPESMAR II, México, for the support given to this research. We would also like to acknowledge J. Cutz de Ocampo, O. Bernal-Castañeda, K. Leyva-Moguel, G. Arámburu-Gullian and S. Mikel for their field and lab assistance.

\section{References}

Adams, M. R., \& Moss, M. O. (2000). Food microbiology (2nd ed.). Cambridge: Royal Society of the Chemistry.

Analytical Methods Committee - AMC. (1978). Determination of fish content of coated fish products. Analyst, 103(1230), 973-978. http:// dx.doi.org/10.1039/an9780300973. PMid:707815.

Antoine, F., Wei, C., Otwell, W., Sims, C., Littell, R., Hogle, A., \& Marshall, M. (2002). TVB-N correlation with odor evaluation and aerobic plate count in mahi-mahi (Coryphaena hippurus). Journal of Food Science, 67(9), 3210-3214. http://dx.doi.org/10.1111/j.1365-2621.2002. tb09567.x.

Ashie, I. N. A., Smith, J. P., Simpson, B. K., \& Haard, N. F. (1996). Spoilage and shelf life extension of fresh fish and shellfish. Critical Reviews in Food Science and Nutrition, 36(1-2), 87-121. http://dx.doi. org/10.1080/10408399609527720. PMid:8747101.

Association of Official Analytical Chemists - AOAC. (2007). Official Methods of Analysis of AOAC International (18th ed.). Gaithersburg: AOAC.

Barbosa, A., \& Vaz-Pires, P. (2004). Quality index method (QIM): development of a sensory scheme for common octopus (Octopus vulgaris). Food Control, 15(3), 161-168. http://dx.doi.org/10.1016/ S0956-7135(03)00027-6.

Bermúdez-Aguirre, D., \& Welti-Chanes, J. (2016). Chilled foods: effects on shelf-life and sensory quality. In Encyclopedia of Food and Health. Reference module in food science (pp. 14-18). Oxford: Elsevier.

Botta, J. R. (1995). Evaluation of seafood freshness quality. New York: John Wiley \& Sons.

Burnham, V. E., Janes, M. E., Jakus, L. A., Supan, J., DePaola, A., \& Bell, J. (2009). Growth and survival differences of Vibrio vulnificus and Vibrio parahaemolyticus strains during cold storage. Journal of Food Science, 74(6), 314-318. http://dx.doi.org/10.1111/j.17503841.2009.01227.x. PMid:19723217.

Dalgaard, P. (2000). Fresh and lightly preserved seafood. In: C.M.D. Man \& A.A. Jones (Eds.), Shelf-life evaluation offoods (pp. 110-139). London: Aspen Publisher Inc.

Ercolini, D., Russo, F., Nasi, A., Ferranti, P., \& Villani, F. (2009). Mesophilic and psychrotrophic bacteria from meat and their spoilage potential in vitro and in beef. Applied and Environmental Microbiology, 75(7), 1990-2001. http://dx.doi.org/10.1128/AEM.02762-08. PMid:19201980.

European Commission - EC. (1996). Council regulation $N^{\circ} 2406 / 96$ of 26 November 1996 laying down common marketing standards for certain fishery products (O J 334:9-13). Brussels: EC.

European Commission - EC. (2003). Commission recommendation of 10 January 2003. concerning a coordinated program for the official control of foodstuffs for 2003 (2003/10/EC, O J 7:76-81). Brussels: EC.
Fichi, G., Cardeti, G., Perrucci, S., Vanni, A., Cersini, A., Lenzi, C., De Wolf, T., Fronte, B., Guarducci, M., \& Susini, F. (2015). Skin lesion-associated pathogens from Octopus vulgaris: first detection of Photobacterium swingsii, Lactococcus garvieae and betanodavirus. Diseases of Aquatic Organisms, 115(2), 147-156. http://dx.doi. org/10.3354/dao02877. PMid:26203886.

González de la Rosa, M. E., Santos, J., \& Solís, M. J. (1998). Evaluation of Octopus maya north coast of Campeche, El Timón. México: Ministry of Fisheries.

Gram, L., \& Dalgaard, P. (2002). Fish spoilage bacteria-problems and solutions. Current Opinion in Biotechnology, 13(3), 262-266. http:// dx.doi.org/10.1016/S0958-1669(02)00309-9. PMid:12180103.

Hamada-Sato, N., Usui, K., Kobayashi, T., Imada, C., \& Watanabe, E. (2005). Quality assurance of raw fish based on HACCP concept. Food Control, 16(4), 301-307. http://dx.doi.org/10.1016/j.foodcont.2004.02.001.

Hu, Y., Huang, Z., Li, J., \& Yang, H. (2012). Concentrations of biogenic amines in fish, squid and octopus and their changes during storage. Food Chemistry, 135(4), 2604-2611. http://dx.doi.org/10.1016/j. foodchem.2012.06.121. PMid:22980848.

Hurtado, J. L., Borderías, A. J., Montero, P. E., \& An, H. (1999). Characterisation of proteolytic activity in octopus (Octopus vulgaris) arm muscle. Journal of Food Biochemistry, 23(4), 469-483. http:// dx.doi.org/10.1111/j.1745-4514.1999.tb00031.x.

Hurtado, J. L., Montero, P. E., \& Borderias, A. J. (2001). Chilled storage of pressurized octopus (Octopus vulgaris) muscle. Journal of Food Science, 66(3), 400-406. http://dx.doi.org/10.1111/j.1365-2621.2001. tb16117.x.

Huss, H. H. (1995). Quality and quality changes in fresh fish (FAO Fishery Technical Paper, № 348). Rome: FAO.

International Commission of Microbiological Specifications for Foods - ICMSF. (1996). Microorganisms in foods. London: Blackie Academic \& Professional.

International Organization for Standardization - ISO. (1999). ISO 2859-1: sampling procedures for inspection by attributes. Part 1: sampling schemes indexed by acceptance quality limit $(A Q L)$ for lotby-lot inspection (2nd ed.). Switzerland: ISO.

Jiang, Q. Q., Dai, Z. Y., Zhou, T., Wu, J. J., Bu, J. Z., \& Zheng, T. L. (2013). Histamine production and bacterial growth in mackerel (Pneumatophorus japonicus) during storage. Journal of Food Biochemistry, 37(2), 246-253. http://dx.doi.org/10.1111/jfbc.12021.

Kraft, A. A. (1992). Psychrotrophic bacteria in food: disease and spoilage. Boca Raton: CRC Press.

Legendre, P., \& Legendre, L. (1998). Numerical ecology (2nd ed). Amsterdam: Elsevier.

Liston, J. (1980). Fish and shellfish and their products. In International Commission on Microbiological Specifications for Foods - ICMSF (Ed.), Microbial ecology of food (Vol. 2, pp. 567-605). New York: Academic Press.

McPhee, J. D., \& Griffiths, M. W. (2011). Psychrotrophic bacteria, Pseudomonas spp. In J. W. Fuquay, P. F. Fox, \& P. L. H. McSweeney (Eds.), Encyclopedia of dairy sciences (2nd ed., pp. 379-383). London: Academic Press.

Mexican Official Norm - NOM. (1993). NMX-F-535: fishery products. Fresh octopus frozen. Specifications. Mexico: NOM.

Mexican Official Norm - NOM. (2009). NOM-242-SSA1: productos de la pesca frescos, refrigerados, congelados y procesados. Especificaciones sanitarias y métodos de prueba. Mexico: NOM.

Mikš-Krajnik, M., Yoon, Y. J., Ukuku, D. O., \& Yuk, H. G. (2016). Volatile chemical spoilage indexes of raw Atlantic salmon (Salmo salar) stored under aerobic condition in relation to microbiological 
and sensory shelf lives. Food Microbiology, 53(Pt B), 182-191. http:// dx.doi.org/10.1016/j.fm.2015.10.001. PMid:26678146.

Moini, S., Sotoodeh, A. M., Haghoo, A., Moslemi, M., Hosseini, S. V., Regenstein, J. M., Feás-Sanchez, X., Aflaki, F., \& Yadollahi, F. (2012). Changes in biogenic amines and bacteria of Tiger-toothed croaker (Otolithes rubber) during ice storage. Journal of Aquatic Food Product Technology, 21(2), 147-155. http://dx.doi.org/10.108 0/10498850.2011.587941.

Ridell, J., \& Korkeala, H. (1997). Minimum growth temperatures of Hafnia alvei and other Enterobacteriaceae isolated from refrigerated meat determined with a temperature gradient incubator. International Journal of Food Microbiology, 35(3), 287-292. http://dx.doi.org/10.1016/ S0168-1605(96)01248-2. PMid:9105940.

Scott, D., Porter, R., Kudo, G., Miller, R., \& Koury, B. (1988). Effect of freezing and frozen storage of Alaska pollack on the chemical and gel-forming properties of surimi. Journal of Food Science, 50, 723-726. http://dx.doi.org/10.1111/j.1365-2621.1988.tb07704.x.

Shalaby, A. R. (1996). Significance of biogenic amines to food safety and human health. Food Research International, 29(7), 675-690. http://dx.doi.org/10.1016/S0963-9969(96)00066-X.

Sharifian, S., Alizadeh, E., Mortazavi, M. S., \& Moghadam, M. S. (2014). Effect of refrigerated storage on the microstructure and quality of Grouper (Epinephelus coioides) fillets. Journal of Food Science and Technology, 51(5), 929-935. http://dx.doi.org/10.1007/s13197-0110589-4. PMid:24803700.

Shewan, J. M., Macintosh, R. G., Tucker, C. G., \& Ehrenberg, A. C. (1953). The development of a numerical scoring system for the sensory assessment of the spoilage of wet white fish stored in ice. Journal of the Science of Food and Agriculture, 4(6), 283-298. http:// dx.doi.org/10.1002/jsfa.2740040607.
Sieburth, J. McN. (1971). Distribution and activity of oceanic bacteria. Deep-Sea Research, 18, 1111-1121. http://dx.doi.org/10.1016/00117471(71)90096-9.

Solís-Ramírez, M. J. (1997). Octopus maya: biology and fishery in Mexico. In M. Lang, F.G. Hochberg, R.A. Ambrose \& J.M. Engle (Eds.), Proceedings the fishery and market potential of Octopus in California (pp. 105-113). Los Angeles: Smithsonian Institution/ University of Southern California.

Takahashi, H., Ogai, M., Miya, S., Kuda, T., \& Kimura, B. (2015). Effects of environmental factors on histamine production in the psychrophilic histamine-producing bacterium Photobacterium iliopiscarium. Food Control, 52, 39-42. http://dx.doi.org/10.1016/j. foodcont.2014.12.023.

Ten Brink, B., Damink, C., Joosten, H. M., \& Huis in 't Veld, J. H. (1990). Occurrence and formation of biologically active amines in foods. International Journal of Food Microbiology, 11(1), 73-84. http://dx.doi.org/10.1016/0168-1605(90)90040-C. PMid:2223522.

Thomas, S. B. (2008). Methods of assessing the psychrotrophic bacterial content of milk. The Journal of Applied Bacteriology, 32(3), 269-296. http://dx.doi.org/10.1111/j.1365-2672.1969.tb00974.x. PMid:4904963.

Torido, Y., Takahashi, H., Kuda, T., \& Kimura, B. (2012). Analysis of the growth of histamine-producing bacteria and histamine accumulation in fish during storage at low temperatures. Food Control, 174-177. http://dx.doi.org/10.1016/j.foodcont.2012.01.009.

US Food and Drug Administration - FDA. (2001). FDA and EPA safety levels in regulations and guidance: fish and fisheries products hazards and controls guidance (285 p.). Washington: US Food and Drug Administration.

Woyewoda, A. D., Shaw, S. J., Ke, P. J., \& Burns, B. G. (1986). Recommended laboratory methods for assessment of fish quality (Canadian Technical Report of Fisheries and Aquatic Sciences, No 1448). Halifax: Department of Fisheries and Oceans. 